\title{
Comparison of chemical composition and in vitro organic matter digestibility of herbage samples at different stages of maturity before and after collection through oesophageal fistula
}

\author{
Carmen Valdés ${ }^{1}$, F.J. Giráldez ${ }^{2}$, A.R. Mantecón ${ }^{2}$ \\ and F.F. Bermúdez ${ }^{2}$ \\ 'Departamento de Produccion Animal I. Universidad de León \\ 24071 León, Spain \\ ${ }^{2}$ Estación Agricola Experimental (CSIC) \\ Apdo. 788. León, Spain
}

(Received 17 June 1996; accepted 13 September 1996)

\section{ABSTRAC'}

To cvaluate the influence of maturity stage of herbage on possible changes in chemical composition and in vitro organic matter digestibility (IVOMD) of cxtrusae from oesophageally fistulated sheep compared to the corresponding feed sample, four trials were conducted with freshly cut herbage samples of a Lolium-Festuca-Trifolium sward in May, June, July and September. Sixteen oesophageally-fisiulated Churra ewes were assigned to four balanced groups of four animals. One animal from each group was assigned to a trial. Samples of $250 \mathrm{~g}$ of herbage were fed to each animal in the morning of the thrce days of cach period. There were no refusals. Moisture and ash contents were higher $(P<0.01)$ in extrusa than in herbage samples in all the periods. The nitrogen $(\mathrm{N})$ content of extrusa samples were up to 19.2 and $8.6 \%$ higher than in corresponding herbage samples in May and June, respectively. $\Lambda$ significant decrease of $7.8 \%$ in extrusac $N$ content occurred in July, while and the $5 \%$ difference betwecn extrusac and herbage observed in September was not significant $(P>0.10)$. Differences in NDF, ADF and cellulose between extrusa and herbage samples were significant $(P<0.01)$ only in July. Lignin concentration in extrusac was higher $(P<0.05)$ than in herbage samples in May and a significant $(\mathrm{P}<0.05)$ decrease in lignin content was observed in July and Scptember. A small but significant $(\mathrm{P}<0.05)$ increase in the IVOMD value of extrusae was obtained in May.

KEY WORDS: oesophageal fistula, shecp, nutritive value 


\section{INTRODUCTION}

Chemical composition and in vitro digestibility of diets for grazing herbivores are commonly determined from forage samples collected from oesophageally fistulated animals (extrusae). However, collection of dietary samples in this manner can introduce a source of bias due to the combined processes of mastication, salivary contamination, incomplete recovery and leaching of nutrients (Lesperance et al., 1974; Holechek et al., 1982). Drying of extrusae in an oven is the most frequently used method of preparing samples (Holechek et al., 1982), despite existing reports (Lesperance et al., 1974; Scales et al., 1974; Burritt et al., 1988; Papachristou and Nastis, 1994) which indicate that oven drying may increase neutral detergent fibre (NDF) and lignin content and depress the in vitro organic matter digestibility (IVOMD). On the other hand, oven drying may also affect the chemical composition of forage samples collected by hand (Lesperance and Bohman, 1964; Acosta-Gonzalez and Kothmann, 1978). Although some studies comparing the chemical composition and IVOMD of extrusae and consumed herbage eaten have shown that changes in chemical composition are different in different forages (Lesperance et al., 1974; Scales et al., 1974; Holecheck et al., 1982), there is a lack of information about the influence of the stage of maturity of herbage on these changes.

An attempt was made in this study to evaluate the influence of herbage maturity on possible changes in chemical composition and IVOMD of extrusae from ocsophageally fistulated sheep when compared to the corresponding feed sample.

\section{MATERIAL AND METHODS}

Four trials were conducted with freshly cut herbage samples of a sward that had been sown with a mixture of Lolium perenne, Festuca arundinacea and Trifolium repens. In order to obtain samples of herbage at varying stages of maturity, herbage was harvested on three successive days in May, June and July, respectively. Representative samples of autumn regrowth were cut in September, after harvesting the whole sward at the end of August. Herbage samples were used in each trial immediately after having been taken.

Sixteen Churra ewes fistulated at the oesophagus were divided into four balanced groups of four animals, one of each was assigned to a trial. The animals werc maintained grazing on a plot of the sward previously described. From the day before the start of the trial until its last day, four corresponding sheep were held indoors in individual pens. Samples of $250 \mathrm{~g}$ of herbage were fed to each animal in the morning of the three days of each period. There were no refusals. 
All offered feeds were consumed immediately $(15-30 \mathrm{~min})$, the extrusa samples (solid and liquid) were collected and frozen. After having been weighed and dried, extrusa samples obtained from the same animal were pooled for analytical determinations. To avoid ruminal contamination, animals were kept off feed overnight. Samples of herbage were also taken and dried each day, and pooled for analytical determinations.

Herbage and extrusa samples were dried in a forced air oven at $60^{\circ} \mathrm{C}$ to a constant weight and moisture content was calculated as weight loss. After drying, all samples were ground to pass a $1-\mathrm{mm}$ screen. Ash content was determined using an AOAC (1980) method. Except moisture and ash contents, the data were expressed on an ash- free [(organic matter (OM)]) basis. In vitro organic matter digestibility (IVOMD) was determined in herbage and extrusa samples by the technique of Tilley and Terry (1963). Samples were also analysed for nitrogen by the Kjeldahl procedure (AOAC, 1980). Neutral detergent fibre (NDF), acid detergent fibre ( $\mathrm{NDF}$ ), cellulose (CEL) and permanganate lignin (LIG) contents were analysed according to Goering and Van Soest (1970).

Recovery of eaten herbage in extrusae was calculated on a dry matter basis and expressed as percentage units.

The Student's t test was used as a test of significance between the analysed fractions of the herbage and extrusa samples. The effect of period (May, June, July or September) on recovery of herbage and on changes in analytical values were obtained by subjecting the data to one-way analysis of variance using the general linear model procedure of the Statistical Analysis Systems Institute (SAS, 1988). The least significant difference procedure (LSD) was used to test for significant differences between means.

\section{RESULTS}

The amount of herbage dry matter recovered through the oesophageal fistula per $100 \mathrm{~g}$ dry matter eaten was calculated from the dry weight of herbage offered and the dry weight of the extrusae. Mean values of dry matter recovery varied from $33.3 \%$ in July to the highest $(\mathrm{P}<0.05)$ mean value $63.8 \%$, reached in June (see Figure 1). High variability between animals was observed, as C.V. were $28.23,22.56,54.53$ and $24.12 \%$ in May, June, July and September, respectively.

Chemical composition and IVOMD of herbage and oesophageal-fistula samples are given in Table 1 . Moisture and ash contents were higher $(P<0.01)$ in extrusa than in herbage samples in all the periods. When increases in moisture and ash contents were expressed as g component added per $\mathrm{g}$ of DM, period had a significant $(\mathbf{P}<0.05)$ effect on ash increase, but not on moisture (Table 2$)$. 


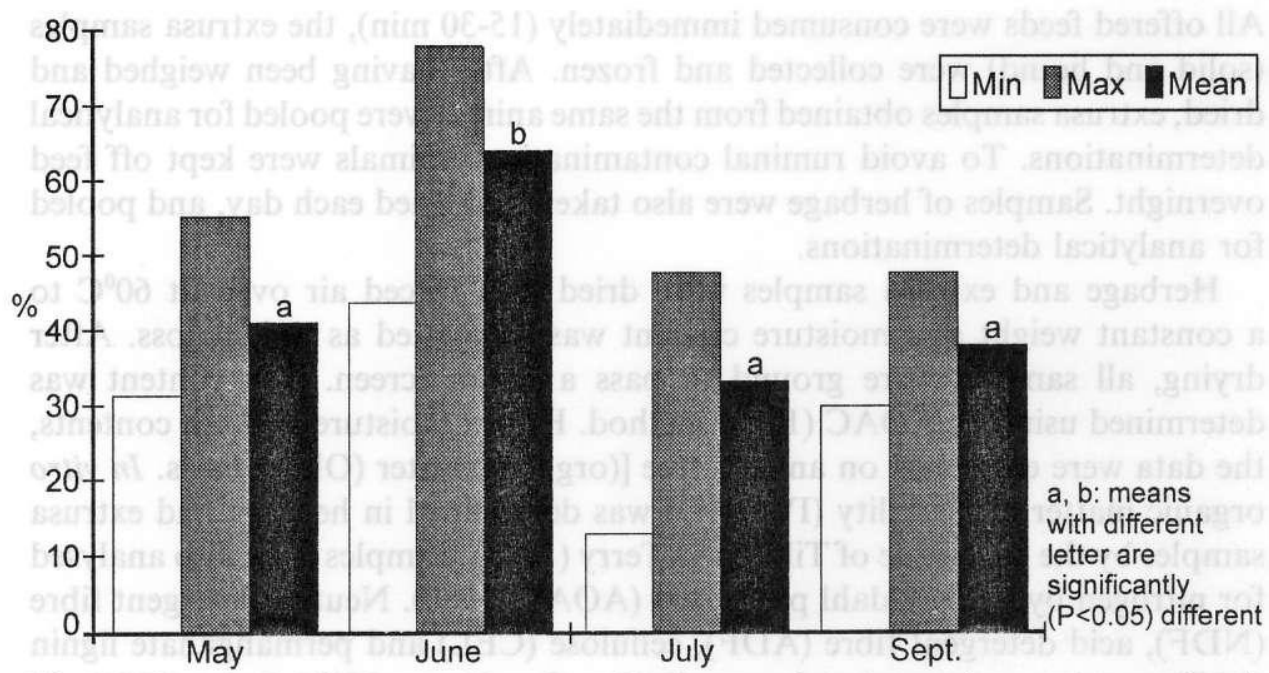

Figure 1. Oesophageal fistula sample recovery of dry matter: minimum, maximun and mean values in each period

Changes in organic fractions (N, NDF, ADF, CEL, LIG) contents and IVOMD were significantly $(\mathrm{P}<0.05)$ affected by period (Table 3 ).

The nitrogen content of extrusa samples was up to 19.2 and $8.6 \%$ higher than in corresponding herbage samples in May and June, respectively, significantly decreased $7.8 \%$ in July, whereas the $5 \%$ difference between extrusae and herbage observed in September was not significant $(P>0.10)$.

Differences in NDF, ADF and CEL between extrusa and herbage samples were significant $(\mathrm{P}<0.01)$ only in July (Table 1$)$, when the values were higher by increasing the values by $4.7,11.3$ and $18.1 \%$, respectively.

Lignin content was numerically higher in extrusa than in herbage samples in May (49.9\%) and June (5.2\%), although the difference was not significant $(\mathrm{P}>0.10)$ in June. In July and September, a significant $(\mathrm{P}<0.01)$ decrease in lignin content was observed, with being the difference between extrusae and herbage more pronounced in September $(-29 \%)$ than in July $(-11.5 \%)$.

IVOMD values of extrusae were numerically higher than in herbage samples in May, June and July, although the difference was significant $(\mathrm{P}<0.05)$ only in the first period. A small decrease, but with a tendency towards statistical significance, $(\mathrm{P}<0.10 ;-3.23 \%)$ was observed in IVOMD in September.

\section{DISCUSSION}

Extrusa samples may contain different amounts of saliva. Considering saliva composition, its addition increases the moisture, ash and nitrogen contents of 
TABLE 1

Chemical composition and in vitro organic matter digestibility (IVOMD) of extrusa and cut herbage samples

\begin{tabular}{|c|c|c|c|c|}
\hline & May & June & July & September \\
\hline & & \multicolumn{3}{|c|}{ Moisture $^{a}$} \\
\hline Extrusa & $870^{* *}$ & $859 * *$ & $851^{* *}$ & $864^{* *}$ \\
\hline Herbage & 770 & 738 & $\begin{array}{l}533 \\
\text { Ash }^{\mathrm{b}}\end{array}$ & 706 \\
\hline Extrusa & $119.5^{* *}$ & $101.9^{* *}$ & $109.2^{* *}$ & $123.9^{* *}$ \\
\hline Herbage & 73.0 & 81.3 & $\begin{array}{c}74.8 \\
\text { Nitrogen }\end{array}$ & 89.8 \\
\hline Extrusa & $28.4^{* *}$ & $19.8^{*}$ & $14.7^{*}$ & 22.8 \\
\hline Herbage & 23.8 & 18.3 & $\begin{array}{c}16.0 \\
\text { Neutral detergent fibre }\end{array}$ & 21.7 \\
\hline Extrusa & 620.4 & 674.4 & $712.8^{* *}$ & 571.1 \\
\hline Herbage & 630.5 & 674.2 & $\begin{array}{l}\quad 680.7 \\
\text { Acid detergent fibre }\end{array}$ & 595.9 \\
\hline Extrusa & 318.9 & 386.5 & $419.3^{* *}$ & $292.4 \ddagger$ \\
\hline Herbage & 313.4 & 382.2 & $\begin{array}{l}376.8 \\
\text { Cellulose }\end{array}$ & 306.3 \\
\hline Extrusa & 274.5 & 317.2 & $342.5 * *$ & 252.7 \\
\hline Herbage & 282.5 & 316.1 & $\begin{array}{l}290.0 \\
\text { Lignin }^{\mathrm{c}}\end{array}$ & 249.5 \\
\hline Extrusa & $44.5^{* *}$ & 69.5 & $76.8^{* *}$ & $40.3^{* *}$ \\
\hline Herbage & 29.9 & \multicolumn{3}{|c|}{ IVOMD $^{i}$} \\
\hline Extrusa & $728^{*}$ & 540 & 490 & $629+$ \\
\hline Herbage & 697 & 529 & 472 & 650 \\
\hline
\end{tabular}

${ }^{2}$ fresh matter basis, g/kg

b dry matter basis, g/kg

' organic matter basis, $\mathrm{g} / \mathrm{kg}$

$\ddagger \mathrm{P}<0.10$ for herbage vs. extrusa samples

* $\mathbf{P}<0.05$ for herbage vs. extrusa samples

** $\mathrm{P}<0.001$ for herbage vs. extrusa samples

TABLE 2

Effect of period of herbage samples taking on salivary contamination'

\begin{tabular}{llllccc}
\hline & May & June & July & September & R.S.D. & Significance \\
\hline Moisture & $3.26^{\text {ba }}$ & $2.74^{\mathrm{a}}$ & $4.77^{\mathrm{b}}$ & $4.15^{\mathrm{ba}}$ & 0.920 & ns \\
Ash & $0.053^{\mathrm{c}}$ & $0.023^{\mathrm{a}}$ & $0.033^{\mathrm{ba}}$ & $0.039^{\mathrm{b}}$ & 0.0074 & $* *$ \\
\hline
\end{tabular}

' values are g/g DM calculated assuming that the increase in both moisture and ash are attributed to saliva contamination

$a, b, c$ different superscript letters on the same row indicate significant differences $(P<0.05)$ 
TABLE 3

Effect of period of herbage samples taking on changes of chemical fractions and in vitro organic matter digestibility (IVOMD) in extrusa samples from oesophageally fistulated sheep ${ }^{1}$

\begin{tabular}{lcccccc}
\hline & May & June & July & September & R.S.D. & Significance \\
\hline $\mathrm{N}^{2}$ & $4.58^{\mathrm{c}}$ & $1.57^{\mathrm{b}}$ & $-1.25^{\mathrm{a}}$ & $1.11^{\mathrm{b}}$ & 1.196 & $* * *$ \\
$\mathrm{NDF}^{2}$ & $-10.12^{\mathrm{a}}$ & $0.18^{\mathrm{ab}}$ & $32.15^{\mathrm{b}}$ & $-24.82^{\mathrm{a}}$ & 19.932 & $*$ \\
$\mathrm{ADF}^{2}$ & $6.62^{\mathrm{a}}$ & $4.38^{\mathrm{a}}$ & $42.49^{\mathrm{b}}$ & $-13.86^{\mathrm{a}}$ & 12.796 & $* *$ \\
Ccllulosc $^{2}$ & $-8.02^{\mathrm{a}}$ & $1.06^{\mathrm{a}}$ & $52.49^{\mathrm{b}}$ & $3.29^{\mathrm{a}}$ & 11.038 & $* * *$ \\
Lignin $^{2}$ & $14.63^{\mathrm{a}}$ & $3.44^{\mathrm{c}}$ & $-10.01^{\mathrm{b}}$ & $-16.47^{\mathrm{a}}$ & 3.103 & $* * *$ \\
IVOMD $^{\mathrm{a} O M}$ & $31^{\mathrm{b}}$ & $11^{\mathrm{b}}$ & $18^{\mathrm{b}}$ & $-21^{\mathrm{a}}$ & 15.4 & $*$ \\
\hline
\end{tabular}

' values are determined by substracting concentration of herbage components from extrusa component.

${ }^{2}$ difference is expressed in $\mathrm{g} / \mathrm{g} \mathrm{OM}$

$a, b, c$ different superscript letters on the same row indicate significant differences $(\mathrm{P}<0.05)$

samples. Moreover, addition of saliva could influence chemical composition of extrusae in another way, as far as the moisture content of samples can affect the formation of artefact lignin during the oven-drying process (Van Soest, 1994).

In our experiment, the moisture content was higher in oesophageal than in herbage samples, a fact that can be attributed to salivary contamination. Subtraction of the moisture of herbage samples from the moisture of the oesophageal-fistula collected herbage could indicate that 3.26, 2.74, 4.77 and $4.15 \mathrm{~g}$ of saliva were added for each gram of dry matter collected, in May, June, July and September, respectively. These values are slightly lower than those reported by Lespcrance et al. (1960), Little (1972) and Acosta and Kothmann (1978) and are in the range of the values obtained in cows using the cardial collection method (Church, 1988). From May to July salivary addition was directly related to both initial dry matter and lignin contents in herbage, which is consistent with an increasing salivary secretion as the fibrosity and dry matter content of the diet increase (Pond et al., 1987).

Ash content of extrusae was higher than that of herbage samples, the difference varied from $46.5 \mathrm{~g} / \mathrm{kg} \mathrm{DM}$ in May to $34.1 \mathrm{~g} / \mathrm{kg} \mathrm{DM}$ in September. These differences are in the range of those reported by Lesperance et al. (1974) for roughage diets and by Saul et al. (1986) for hay samples, and can be explained by the addition of saliva.

$\mathrm{N}$ content of extrusae could have been increased by addition of saliva. $\mathrm{N}$ content of saliva is variable since it contains other constituents, but it is usually in the order of $0.1-0.2 \%$. However, in our experiment, although saliva was added in all cases, the $\mathrm{N}$ content was only higher in extrusae compared to herbage in May and June, and was lower in July, while no difference was detected in September. One of the main factors influencing the $\mathrm{N}$ content of saliva is the $\mathrm{N}$ content of the diet : both total and urea $\mathrm{N}$ may be increased by an increased 
intake of dietary $\mathrm{N}$, and it has been estimated that $4-22 \%$ of dietary $\mathrm{N}$ might be recycled to the rumen via saliva (Church, 1988). The increases in $\mathrm{N}$ content obtained in May, June and September were in the order of $5-16 \%$ and could be accounted for by salivary contamination. However, salivation is not the only possible source of error when extrusae are used as representative samples of consumed herbage, and other factors should be considered to explain the differences between herbage and extrusa samples. $\mathrm{N}$ contents of fistula samples higher than those of corresponding forage have been recorded (Lesperance et al., 1974; Scales et al., 1974; Saul et al., 1986) and attributed to salivary contamination. However, some other studies have shown a lack of differences in $\mathrm{N}$ content; no effect of salivary contamination on sample $\mathrm{N}$ (Holechek et al., 1982), or a partial compensation between salivary addition and leaching of $\mathrm{N}$ (Barth et al., 1971) have been suggested to explain it.

Although it is commonly assumed that representative samples of herbage can be obtained even if recovery through the fistula is incomplete (Lesperance et al., 1974), some differences in chemical composition between extrusac and herbage might be explained by a selective recovery of herbage through oesophageal fistula, which could be more pronounced with poor recoveries.

The dry matter recoverics obtained in this experiment varied from $33.3 \%$ in July to $63.8 \%$ in June. Incomplete recoveries have been recorded by many other authors. Working with oesophageally fistulated sheep in similar pen-feeding experiments, values ranging from 20 to $100 \%$ of the OM (Arnold et al., 1964), from 53 to $73 \%$ of the DM (Grimes et al., 1964) and from 59 to $68 \%$ of the OM (Blackstone et al., 1965) have been reported. It seems that, as pointed out Lesperance et al. (1974), although the use of oesophageally fistulated animals to sample herbage is based on the assumption that a complete collection of ingested forage will be obtained in the sampling process, absolute collection rarely, if ever, occurs. On the other hand, Lesperance et al. (1974) suggested that a high fibre content might increase the recovery problem. However, as in our experiment, a lack of relationship between fibreness of forage and recovery have been reported by Blackstone et al. (1965) in sheep and by Cohen (1979) in cattle.

Differences between extrusa and herbage samples in NDF, ADF and CEL contents were inconsistent with the findings of Saul et al. (1986) who showed that extrusae contains a higher ratio of cell contents to structural material than the feed eaten, with the greatest divergence occurring with feeds with high fibre content. However, increases (Kiesling et al., 1969; Lesperance et al., 1974), both increases and no differences (Scales et al., 1974), decreases (Lesperance et al., 1960) and no differences (Lesperance et al., 1974) between extrusae and herbage in both ADF and CEL have been reported.

In our experiment the increased values of NDF, ADF and CEL contents observed in July extrusae would appear to reffect the loss of cell solubles rather 
than increases of chemical fractions per se. This is also consistent with the decrease in $\mathrm{N}$ and in lignin content, assuming that part of the so-called ,lignin" is an artefact resulting from oven-drying (Van Socst, 1994). Formation of artefact lignin depends on the initial moisture content of the sample, temperature and rate of drying, as well as initial chemical composition of samples. Although pathways for artefact lignin synthesis remain unclear, it seems that reactions are enhanced by moisture, soluble sugars and amino acid contents. Clearly, oven-drying can affect chemical composition of both extrusa and herbage samples. However, changes induced by oven-drying are more marked for samples containing high proportions of moisture. Extrusa samples always contain higher proportions of moisture as a result of saliva addition. Thus, oven-drying is expected to produce a more marked effect on chemical composition of extrusa than on herbage samples (Papachristou and Nastis, 1994).

Differences between cxtrusa and herbage samples in IVOMD, although significant in June, never represented more than $4 \%$ of the initial value. Other authors (Barth and Kazzal, 1971; Scales et al., 1974; Cohen, 1979; Saul et al., 1986) have all shown that the IVOMD of extrusae can be higher than that of the feed consumed but the differences were often small and variable.

\section{CONCLUSIONS}

Differences between herbage and extrusa samples have been found in both chemical composition and IVOMD and maturity stage of herbage had a significant effect on these changes. However, the collection process does not cause an important bias in IVOMD values, whereas the changes in chemical composition should be carefully considered. The differences between $\mathrm{N}$ content in herbage and extrusa samples represented more than $5 \%$ of herbage values, and they were more pronounced in May. Except for lignin, the differences in NDF and its fractions never represented more than $5 \%$ of the herbage values. We concluded that information obtained from extrusa samples can be reasonably considered as representative of some nutritive parameters of herbage, but the technique should be treated with great caution, because $\mathrm{N}$ and lignin contents of extrusa can give biased values of forage consumed, and the bias can increase with the immaturity of herbage. 


\section{REFERENCES}

A.O.A.C., 1980. Official Methods of Analysis of the Association of Official Agricultural Chemist. 13th Edition. Washington, DC

Acosta-Gonzalcz R.A., Kothmann M.M., 1978. Chemical composition of esophageal-fistula forage samples as influenced by drying method and salivary leaching. J. Anim. Sci. 47, 691-698

Arnold G.W., McManus W.R., Bush I.G., Ball J., 1964. The use of sheep fitted with oesophageal fistulas to measure dict quality. Aus1. J. Exp. Agric. Anim. IIusb. 4, 71-79

Barth K.M., Chandler J.F., Fryer, M.E., Wang. II.C., 1970. Effects of saliva and drying temperature on composition and digestibility of forage samples collected through esophageal fistulas. J. Anim. Sci. 31, 794-798

Barth K.M., Kazzal N.T., 1971. Separation of true selective grazing by cattle from effects of the esophageal fistula. J. Anim. Sci. 33, 1124-1128

Blackstone J.B., Rice R.W., Johnson W.M., 1965. A study of the csophageal fistula technique. Proc. West. Sec. Amer. Soc. Anim. Sci. 16, 75

Burritt E.A.: Pfister J.A:, Malechek J.C., 1988. Tifect of drying method on the nutritive composition of esoplrageal listula forage samples: influence of maturity. J. Range Manage. 41, 346-349

Church D.C., 1988. Salivary function and production. In: D.C. Church (Editor.) The ruminant animal. Digestive physiology and nutrition. Reston Book, New Jersey, pp. 117-124

Cohen R.D.H., 1979. Factors influencing the estimation of the nutritive value of the diet selected by cattle fistulated at the oesophagus. I. Agric. Sci., Camb. 93, 607-618

Goering I1.K., Van Soest P.J., 1970. Forage fiber analyses. ARS, USDA Agricultural Handbook, No. 379

Grimes R.C., Watkin B.R., May P.F., 1964. The botanical and chemical analysis of herbage samples obtained from sheep fitted with oesophageal fistulae. J. Brit. Grassl. Soc. 20, 168-173

Holecheck J.I., Vavra M., Pieper R.D., 1982. Methods for determining the nutritive quality of range ruminant diets: $A$ Review. J. Anim. Sci. 54, 363-375

Kiesling H.E., Nelson A.B., Herbel C.H., 1969. Chemical composition of Tohosa grass collected by hand-plucking and esophagcal-fistulated stecrs. J. Range Manage. 22, 155-159

Lesperance A.L., Bohman V.R., 1964. Chemical changes in forage induced by sample preparation. Proc. West. Amer. Soc. Anim. Sci. 15, 54-57

Lesperance A.L., Bohman V.R., Marble D.W. 1960. Development of techniques for evaluating grazed forage. J. Dairy Sci. 43, 682-689

Lesperance A.L., Clanton D.C., Nelson A.B., Theurer C.B., 1974. Factors affecting the apparent chemical composition of fistula samples. University of Nevada, Experimental Station Bull. T18, pp. 30

Little D.A., 1972. Studies on cattle with oesophageal fistulae. The relation of the chemical composition of feed to that of the extruded bolus. Aust. J. Exp. Agr. Anim. Husb. 12, 126-130

Papachristou T.G., Nastis A.S., 1994. Changes in chemical composition and in vitro digestibility of oesophageal fistula and hand plucked foragc samples due to drying method and stage of maturity. Anim. Feed Sci. Tcchnol. 46, 87-95

Pond K.R., Luginbush J-M., Burns J.C., 1987. Salivation. mastication and rumination. Limits to intake by beef cattle. In: Feed Intake by Beef Cattle. 1986 Fced Intake Symposium. Oklahoma. pp. $160-172$

SAS Institutc Inc., 1988. SAS/ST AT TM User's Guide, Release 6.03 Edition. SAS Institute Inc. Cary, USA

Saul G.R., Flinn P.C., Heard J.F., 1986. The nutritional analysis of roughages belore and after mastication by ocsophageally fistulated sheep. Proc. Aust. Soc. Anim. Prod. 16, 351-354 
Scales G.H., Streeter C.L., Denham A.H., Ward G.M., 1974. Effect of mastication, salivary contamination and leaching on the chemical composition of forage samples collected via esophageal fistulae. J. Anim. Sci. 38, 1278-1283

Tilley J.M.A. and Terry R.A., 1963. A two-stage technique for the in vitro digestion forage crops. J. Brit. Grassl. Soc. 18, 104-111

Van Soest P.J., 1994. Nutritional Ecology of the Ruminant. 2nd. Edition. Cornel] University Press, Ithaca, pp. 173-175

\section{STRESZCZENIE}

Porównanie składu chemicznego i strawności substancji organicznej in vitro zielonki, zbierancj w różnych okresach dojrzałości, oznaczanych w próbach świeżych i pobieranych z przetoki przelykowej

Badano wpływ stopnia dojrzałości roślin (Lolium, Festuca, Trifolitum) na różnice między składem chemicznym i strawnosicią substancji organicznej in vitro (IVOMD) prób pobieranych z przetoki przełykowej owiec i odpowiadających prób świeżej zielonki. Doświadczenie przeprowadzono w maju, czerwcu, lipcu i wrześniu na szesnastu maciorkach rasy Churra z przetokami przełykowymi (4 grupy po 4 zwierzęta). $250 \mathrm{~g}$ porcje każdej z zielonek podawano rano przez 3 kolejne dni w każdym miesiącu.

We wszystkich okresach zawartość wody i popiołu była większa $(\mathrm{P}<0,01)$ w próbach pobranych z przetoki niż w świeżej zielonce. W maju i czerwcu zawartość $\mathrm{N}$ w próbach z przetoki była wiçkša niż w zielonce odpowiednio o 19,2 i $8,6 \%$, zaś w lipcu i wrześniu mniejsza odpowiednio o $7,8 \%$ $(\mathrm{P}<0,05)$ i $5 \%(\mathbf{P}>0,10)$. Różnice w zawartości NDF, ADF i CEL między próbami z przetoki a próbami świcżej zielonki były istotne $(\mathrm{P}<0,01)$ tylko $\mathrm{w}$ lipcu. Zawartosc ligniny w próbach z przetoki była większa $(\mathrm{P}<0,05)$ w maju, a mniejsza $(\mathrm{P}<0,05)$ w lipcu i w sierpniu niż w próbach zielonki. Tylko w maju IVOMD prób pobranych z przetoki była większa $(P<0,05)$ niż świeżej zielonki. 